\title{
STARBUCKS (HK) CASE NOTE: THE AMBIGUOUS LIMB OF GOODWILL AND THE TORT OF PASSING OFF
}

\author{
Olivia Lewis*
}

\begin{abstract}
This article looks at the United Kingdom Supreme Court's decision in the case of Starbucks (HK) Ltd $\mathrm{v}$ British Sky Broadcasting Group PLC (Starbucks). In this case Lord Neuberger reaffirmed that the traditional "hard-line approach" is the applicable test for the goodwill limb under the tort of passing off in the United Kingdom. This approach maintains that in order to succeed in a claim for passing off, the claimant must show that they have goodwill in the form of business and customers in the jurisdiction. A significant reputation among a sufficient section of the prospective purchasing public within the jurisdiction (the "soft-line approach") was held to be insufficient. This article critically analyses Lord Neuberger's reasoning in favour of the traditional hard-line approach. It is found that his approach was out of touch with modern commercial reality.
\end{abstract}

In conclusion, it is argued that Lord Neuberger did not strike the appropriate balance between the competing public interests in protection and competition, and it is contended that he should have adopted the more factually inquisitive soft-line approach. This would have brought the United Kingdom into line with what is arguably the more dominant and justifiable trend in other common law jurisdictions, thereby avoiding the enduring uncertainty which is likely to follow this decision.

\section{INTRODUCTION}

On 13 May 2015 Lord Neuberger delivered the United Kingdom Supreme Court's decision in Starbucks (HK) Ltd v British Sky Broadcasting Group PLC (Starbucks). ${ }^{1}$ It was hoped that this decision would clarify the law relating to the tort of passing off, which is inconsistently applied in the common law jurisdictions. The confusion arising in relation to the tort is largely due to the ambiguous limb of goodwill in the test for passing off.

* Submitted as part of the LLB(Hons) programme at Victoria University of Wellington. I am extremely grateful to my supervisor, Professor Susy Frankel, for her invaluable insight, guidance and support.

1 Starbucks (HK) Ltd v British Sky Broadcasting Group plc [2015] UKSC 31, [2015] 1 WLR 2628. 
The issue at the heart of this article is whether a claimant who is seeking to maintain an action in passing off need only establish goodwill in the form of a significant reputation among a sufficient section of the prospective purchasing public within the jurisdiction (the "soft-line" approach), or whether they must establish that they have a business with customers in the jurisdiction (the traditional or "hard-line" approach). This article compares these two approaches to the goodwill limb and argues that the softer approach, which is applied by courts in other common law jurisdictions, is more appropriate in today's modern commercial landscape.

Lord Neuberger's reasoning in favour of the hard-line approach is challenged as being unconvincing as it does not fully acknowledge nor successfully rebut the arguments in favour of the soft-line approach. It is found that he does not strike the appropriate balance between the public interests in protection and competition despite this being the main basis for his decision. Consideration is given to how the soft-line approach is applied in other jurisdictions, its implications and how the facts of a case like Starbucks would be decided using this approach. In conclusion, it is contended that the United Kingdom Supreme Court's decision was orthodox and inappropriately simplistic when it should have been contemporary and grounded in the facts of the case. Overall, it is found that the Court should have adopted the soft-line approach and brought the United Kingdom into line with what is arguably the more commercially justifiable trend of the common law jurisdictions.

\section{BACKGROUND: THE TORT OF PASSING OFF}

\section{A Purpose and Implications}

The tort of passing off aims to protect traders and customers against the confusion caused by the tortfeasor's misrepresentation. ${ }^{2}$ The fundamental rule of the tort is summarised by Lord Oliver in Reckitt \& Colman Products v Borden Inc (the Jif Lemon case) as "no man may pass off his goods as those of another". ${ }^{3}$ This is aimed at protecting consumers against deception in relation to a trade source or to a business connection. The tort is the key way by which the courts protect unregistered trademarks. ${ }^{4}$

2 The Leather Cloth Company Ltd v The American Leather Cloth Company Ltd (1865) 29 JP 675, 11 ER 1435 at 538 per Lord Kingsdown; and Erven Warnink BV v J Townend \& Sons (Hull) Ltd [1979] AC 731 (HL) per Lord Diplock [the Advocaat case].

3 Reckitt \& Colman Products Ltd (t/a Colmans of Norwich) v Borden Inc [1990] 1 WLR 491 (HL) at 499 [the Jif Lemon case].

4 Susy Frankel Intellectual Property in New Zealand (2nd ed, LexisNexis, Wellington, 2011) at 494. 


\section{$B$ The Nature of Passing off}

Passing off has been referred to as a "protean tort", reflecting that it is inherently flexible and can and should respond to changing business practices. ${ }^{5}$ The term "protean" is also indicative of its elusive nature being entirely a product of case law.

A fundamental feature of the tort is that it protects: ${ }^{6}$

... a right of property not in the mark, name or get-up improperly used, but in the business or goodwill likely to be injured by the misrepresentation made by passing-off one person's goods as the goods of another.

The protection provided by the tort is therefore indirect in the sense that the prohibition on using similar devices is not due to any "property" in the devices themselves, but because the use of those devices might diminish the underlying property that the trader has in his or her goodwill established with customers. ${ }^{7}$ Therefore, a trader must prove that they have sufficient and identifiable goodwill in their name, mark or get-up in order to justify property rights attaching to it.

\section{The General Test: "The Classic Trinity"}

Lord Oliver's "classic trinity" test in the Jif Lemon case has become the most widely recognised test for establishing a passing off claim. ${ }^{8}$ This requires the claimant to establish the following three limbs:

(1) goodwill;

(2) misrepresentation; and

(3) damage or the likelihood of damage.

Misrepresentation is the basis of a passing off claim..$^{9}$ In other frequently cited tests this limb comes first. ${ }^{10}$ However, it is sensible to start with the goodwill limb, as this establishes the property right to

5 The Advocaat case, above n 2, at 730 per Lord Diplock.

6 Star Industrial Co Ltd v Yap Kwee Kor [1976] FSR 256 (PC) at 269 per Lord Diplock (emphasis added).

7 Frankel, above n 4, at 564.

8 The Jif Lemon case, above n 3, at 499.

9 Frankel, above n 4, at 590; supported by Cadbury-Schweppes Pty Ltd v Pub Squash Co Ltd [1981] 1 WLR $193(\mathrm{PC})$.

10 See Lord Diplock's five necessary characteristics for a valid cause of action for passing off in the Advocaat case, above n 2 , at 742 . 
which the other limbs relate. It also clarifies the misrepresentation and damage that is required in order to maintain a passing off claim. ${ }^{11}$

\section{The Balance Between Protection and Competition}

The law of passing off must strike the appropriate balance between two competing public interests: free competition on the one hand, and protection of a trader against unfair competition on the other. ${ }^{12}$ If the test is too restrictive it risks placing too great of a burden on new competitors, who may be prevented from trading on a level playing field with established market players, or on terms that may be disadvantageous to both prospective competitors and consumers. ${ }^{13}$ It is in the public interest to allow for some imitation as this is conducive to all developments: commercial, artistic, professional and scientific. ${ }^{14}$ However, if the test is too permissive, it risks allowing new competitors to exploit or free-ride off the efforts, inventiveness and expenditure of those established traders who have already developed a reputation in the market. ${ }^{15}$ Therefore, it is important to distinguish between copying and misrepresentation: the courts only protect against the latter.

The appropriate balance seems to be struck by giving established traders protection over their name, mark or get-up, but only if they can show an invasion of their intangible property right goodwill - in that name, mark or get-up. ${ }^{16}$ The definition of goodwill is therefore critical to this balance. If the threshold is too low, it may be too easy for a claimant to show an invasion of their intangible property right, and this may tip the balance too much in favour of protection. However, if it is too high, it risks allowing new entrants to pass off their goods as those of established traders. Thus goodwill must be defined in a way that upholds the high threshold required for establishing property rights, but also in a way that fulfils the purpose of the tort to protect against misrepresentation.

\section{DEFINING GOODWILL}

It has rightly been said that goodwill "is a thing very easy to describe, [but] very difficult to define". ${ }^{17}$ Goodwill is an intangible asset that has been described as "the benefit and advantage of the

11 Edwards Wildman Palmer "Maintain your goodwill" (December/January 2013) World Trademark Review <www.worldtrademarkreview.com> at 88 .

12 Dominion Rent A Car Ltd v Budget Rent A Car Systems (1970) Ltd [1987] 2 NZLR 395 (CA) at 116 per Somers J.

13 Frankel, above n 4, at 490.

14 Starbucks, above n 1, at [61].

15 Frankel, above n 4, at 490.

16 See generally Star Industrial Co Ltd, above n 6.

17 Muller \& Co's Margarine Ltd v Inland Revenue Commissioners [1901] AC 217 (HL) at 233 per Lord Macnaughten. 
good name, reputation, and connection of a business ... the attractive force which brings in custom". ${ }^{18}$ It embodies the connection that consumers make, consciously or subconsciously, with the goods or services, and what consumers have heard about the goods, as well as what they know from personal experience. ${ }^{19}$

\section{A The Traditional Hard-Line Approach}

The United Kingdom has always applied the traditional hard-line approach. ${ }^{20}$ This approach requires an actual carrying on of business and customers in the jurisdiction in order to establish goodwill in a claim for passing off. ${ }^{21}$ The classic authorities that support this approach relied on Lord Macnaughten's dictum in Muller that the "attribute of locality" is common to all cases of goodwill. ${ }^{22}$ This view distinguishes between reputation and goodwill. Reputation may be gained as a result of advertising and may and often does exist without any supporting business or customers. Goodwill on the other hand, "as the subject of proprietary rights", is said to be "incapable of subsisting by itself", having "no independent existence apart from the business to which it is attached". ${ }^{23}$

This approach is strongly territorial, as it emphasises the "local" and "divisible" character of goodwill, holding that passing off protects businesses' goodwill within a particular jurisdiction, as opposed to a general international reputation. ${ }^{24}$ Therefore, if a business is carried out in more than one country there must be separate goodwill in each country. ${ }^{25}$

18 Muller, above n 17, at 233-224.

19 Palmer, above $\mathrm{n} 11$, at 88 .

20 See Muller, above n 17; the Jif Lemon case, above n 3; the Advocaat case, above n 2; Anheuser-Busch Inc $v$ Budejovicky Budvar NP (t/a Budvar Brewery) [1984] FSR 413 (CA); AG Spalding \& Bros v AW Gamage Ltd (1915) 32 RPC 273 (HL); and Alain Bernardin et Cie v Pavilion Properties Ltd [1967] RPC 581 (Ch) [the Crazy Horse case].

21 The Advocaat case, above n 2, at 742; Anheuser-Busch, above n 20, at 462; Star Industrial Co Ltd, above n 6; AG Spalding \& Bros, above n 20, at 284; and the Crazy Horse case, above n 20.

22 Muller, above n 17, at 223-225.

23 Star Industrial Co Ltd, above n 6, at 269 per Lord Diplock, in reliance on the observations of Lord Macnaughten in Muller, above n 17, at 223-225; and Lord Parker in AG Spalding \& Bros, above $\mathrm{n} 20$.

24 See Anheuser-Busch, above n 20, at 470; Star Industrial Co Ltd, above n 6; and AG Spalding \& Bros, above n 20 .

25 Star Industrial Co Ltd, above n 6, at 269. 


\section{B The Modern Soft-Line Approach}

The hard-line approach has not survived in many common law countries, including New Zealand, ${ }^{26}$ Australia, ${ }^{27}$ Canada, ${ }^{28}$ Hong Kong, ${ }^{29}$ India, ${ }^{30}$ and South Africa. ${ }^{31}$ These countries have adopted the softer approach under which goodwill is viewed as "an international commodity" and "business activity within the jurisdiction is no longer a prerequisite for success in a passing off claim". ${ }^{32}$ This approach recognises that in the modern commercial landscape goodwill, as a matter of fact, may transcend territorial boundaries. ${ }^{33}$

The soft-line approach essentially involves a three-fold factual inquiry into whether:

(a) the plaintiff has a significant reputation for their name, mark or get-up, which is recognised as distinguishing their goods and services; ${ }^{34}$

(b) that reputation is known to a sufficient number of prospective purchasers in the jurisdiction; ${ }^{35}$ and

(c) the defendant's use of the plaintiff's name, mark or get-up is likely to lead to confusion in relation to prospective purchasers connecting the source of the defendant's product to the plaintiffs. $^{36}$

26 See generally Dominion Rent A Car, above n 12; Gallaher Ltd v International Brands Ltd (1976) 1 NZIPR 43 (SC); Esanda Ltd v Esanda Finance Ltd [1984] 2 NZLR 748 (HC); Crusader Oil NL v Crusader Minerals New Zealand Ltd (1984) 1 TCLR 211 (HC); and Muzz. Buzz Franchising Pty Ltd v JB Holdings (2010) Ltd [2013] NZHC 159.

27 See generally ConAgra Inc v McCain Foods (Aust) Pty Ltd (1992) IPR 194 (FCA).

28 See generally Orkin Exterminating Co v Pestco Co of Canada (1985) 11 DLR (4th) 84 (ONCJ).

29 See generally Tan-Ichi Company Ltd v Jancar Ltd [1990] FSR 151 (HC).

30 See generally William Grant \& Sons Ltd v McDowell \& Co Ltd [1994] FSR 690 (HC); Jolen Inc v Doctor \& Co 2002 (25) PTC 29 (HC); Ziff-Davis v Jain 1998 (18) PTC 739 (HC); and Dongre v Whirlpool AIR 1995 Del $300(\mathrm{HC})$.

31 Caterham Car Sales and Coachworks Ltd v Birkin Cars Ltd [1998] (3) SA 938 (SCA).

32 Mark Davison and Ian Horak (eds) Shanahan's Australian Law of Trade Marks and Passing Off (5th ed, Lawbook, Pyrmont (NSW), 2013) at 739.

33 Dominion Rent A Car, above n 12, at 406; Caterham Car Sales, above n 31, at [20]; and Dongre $v$ Whirlpool, above $n$ 30, at [12] and [29].

34 The first limb of Lord Oliver's "Classic Trinity" in the Jif Lemon case, above n 3, at 499.

35 Caterham Car Sales, above n 31, at [20]; and ConArga, above n 27, at [132]: note that the reputation must be established in the relevant forum.

36 Orkin Exterminating Co, above n 28, at [63]. 
This analysis takes into account all the circumstances of a particular case and requires judges to make a judgment as to whether the plaintiff has, in a practical and business sense, a reputation in the jurisdiction which is sufficient for a likelihood of deception to occur. ${ }^{37}$

\section{Reconciling this approach with the description of goodwill}

The soft-line approach is still consistent with the description of goodwill as an "attractive force" or "connection", as this suggests it is what draws in or gives rise to the acquisition of customers (which an international reputation is more than capable of doing), but does not go so far as to equate goodwill with business activity or customers in a jurisdiction. ${ }^{38}$ Justice Modern in Orkin Exterminating Co acknowledged that "[v]irtually no words have a single fixed meaning, particularly goodwill". ${ }^{39}$ Therefore, while locality in the form of business and customers in the jurisdiction is often a component of goodwill, this need not always be the case. ${ }^{40}$

\section{This approach involves the limbs of the "classic trinity" working together to produce just results}

The traditional approach arguably places too much emphasis on the goodwill limb, separating it and making it an obstructive gateway to the other limbs of the test for passing off. It is important to remember that misrepresentation lies "at the heart of passing off", as this is what the tort is aimed at protecting against. ${ }^{41}$ It is true that there must be a sufficiently high threshold for the goodwill limb, as this sets the bar for the type of misrepresentation and damage which is required in order to maintain a passing off claim. ${ }^{42}$ However, this high threshold can still be met by requiring a significant reputation among a sufficient number of prospective purchasers in the jurisdiction.

While a claimant can be found to have goodwill without proving misrepresentation or damage, there can be no finding of misrepresentation or damage without establishing that a property right, in the form of goodwill, exists. ${ }^{43}$ A corollary of this is that generally, where there is clear evidence of misrepresentation due to the likelihood of a sufficient number of prospective purchasers thinking a defendant's use of a mark is connected to the plaintiff, the plaintiff will usually have a significant

37 Caterham Car Sales, above n 31, at [20]; and ConAgra, above n 27, at 234, 237 and 269.

38 Muller, above n 17, at 223 and 224. See also Caterham Car Sales, above n 31, at [15].

39 Orkin Exterminating Co v Pestco of Canada, above n 28, at [63].

40 See Caterham Car Sales, above n 31, at [23] per Harms JA.

41 Hodgkinson \& Corby Ltd v Wards Mobility Services Ltd [1994] 1 WLR 1564 (Ch) at 1570. See also Caterham Car Sales, above n 31, at [15]; ConAgra, above n 27, at [119]; and Barbara Lauriat "Passing Off, the Internet, and the Global Marketplace" in Susy Frankel and Daniel Gervais The Internet and the Emerging Importance of New Forms of Intellectual Property (Kluwer Law International BV, Alphen aan den Rijn, 2016) 59 at 79.

42 Edwards Wildman Palmer, above n 11, at 88.

43 Frankel, above n 4, at 564-565. 
reputation or goodwill which deserves protection. ${ }^{44}$ Therefore, while the three limbs of the "classic trinity" need to be established individually, judges should not shut their eyes to clear evidence of misrepresentation when establishing the goodwill limb. ${ }^{45}$ Focusing on the goodwill limb in isolation loses sight of the core purpose of the tort. ${ }^{46}$ It is for this reason that the soft-line approach allows evidence of likely misrepresentation and consequential damage to inform the goodwill inquiry as this can be the most helpful indicator that goodwill exists in the jurisdiction.

\section{THE UNITED KINGDOM SUPREME COURT DECISION IN STARBUCKS}

\section{A Facts}

The appellant claimants, Starbucks (HK) Ltd and PCCW Media Ltd, members of the Hong Kongbased group PCCM, have provided a television subscription service using the name "NOW TV" since $2006 .{ }^{47}$ From 2012, PCCM's NOW TV has been the biggest television service in Hong Kong, with over 1.2 million subscribers, offering around 200 channels in Mandarin, Cantonese and a small number in English. In July 2012 the respondent defendants British Sky Broadcasting Group PLC (Sky) launched a new internet television service under the name "NOW TV" in the United Kingdom. ${ }^{48}$

On 19 April 2012, PCCM began proceedings in the High Court of England and Wales, seeking to prevent Sky from using the name "NOW TV" in the United Kingdom on the grounds that the use of that name amounted to passing off. ${ }^{49}$ At the inception of the use complained of, ${ }^{50}$ PCCM's NOW TV had a reputation among a substantial number of Chinese-speaking residents in the United Kingdom who were aware of the service through exposure to it when visiting or residing in Hong Kong, its online presence on PCCM's website and YouTube channel, and also its availability as inflight entertainment on various international airlines, three of which flew into the United Kingdom. ${ }^{51}$ There was also evidence that since 2009, PCCM had been considering expanding its NOW TV subscription service internationally and in particular to the United Kingdom. ${ }^{52} \mathrm{PCCM}$ had been in discussions with

44 See Orkin Exterminating Co v Pestco of Canada, above n 28, at [63]; and Tot Toys Ltd v Mitchell [1993] 1 NZLR 325 (HC) at 367.

45 See ConAgra, above n 27, at [125]: Hill J said that the question should not be looked at in the abstract; rather, evidence of likely misrepresentation should be taken into account.

46 Lauriat, above $\mathrm{n} 41$, at 78.

47 Starbucks, above n 1, at [3]

48 At [7].

49 At [9].

50 This is the relevant date: see Anheuser-Busch, above n 21, at 462; and Starbucks, above n 1, at [16]

51 Starbucks, above n 1, at [4]-[5].

52 At [6]. 
a potential United Kingdom partner, and in June 2012 they launched a NOW player app aimed at Chinese-speakers in the United Kingdom which was downloaded by just over 2,200 people. ${ }^{53}$ However, critically from the Court's perspective, the fact remained that there were not yet any purchasing customers of PCCM's NOW TV subscription in the United Kingdom. ${ }^{54}$

\section{B High Court and Court of Appeal Decisions}

Justice Arnold dismissed PCCM's claim, holding that passing off was not made out due to PCCM's failure to establish goodwill in the form of customers in the jurisdiction. ${ }^{55} \mathrm{He}$ made a finding of fact that PCCM had a reputation that was modest but more than de minimis. ${ }^{56}$ The key issue he addressed was "whether the viewers of PCCM's programmes in the United Kingdom were customers for its service so as to give rise to a protectable goodwill in the United Kingdom" ${ }^{57}$ Thus, right from the outset Arnold $\mathrm{J}$ adopted the hard-line approach by equating goodwill with the requirement of customers in the jurisdiction. His dismissal of PCCM's claim was therefore inevitable because the body of people in the United Kingdom who associated the mark "NOW TV" with PCCM were not customers in the United Kingdom in the required paying sense, and hence did not represent goodwill under his predetermined definition of the word. ${ }^{58}$ In his view, expanding goodwill to include nonpaying viewers of the service through websites would "stretch the concept of 'customer' to breaking point" and he noted that "hundreds of television channels worldwide would have customers, and hence protectable goodwill, in the [United Kingdom] courtesy of YouTube". 59

Mummery LJ delivering the judgment of the Court of Appeal essentially agreed with Arnold J's analysis and upheld that reputation among a significant number of people in the United Kingdom was not sufficient to establish a passing off claim and so he dismissed the appeal. ${ }^{60}$

\section{The Issue on Appeal to the Supreme Court}

The question to be decided on appeal was whether a claimant who is seeking to maintain an action in passing off need only establish goodwill in the form of a significant reputation among a sufficient

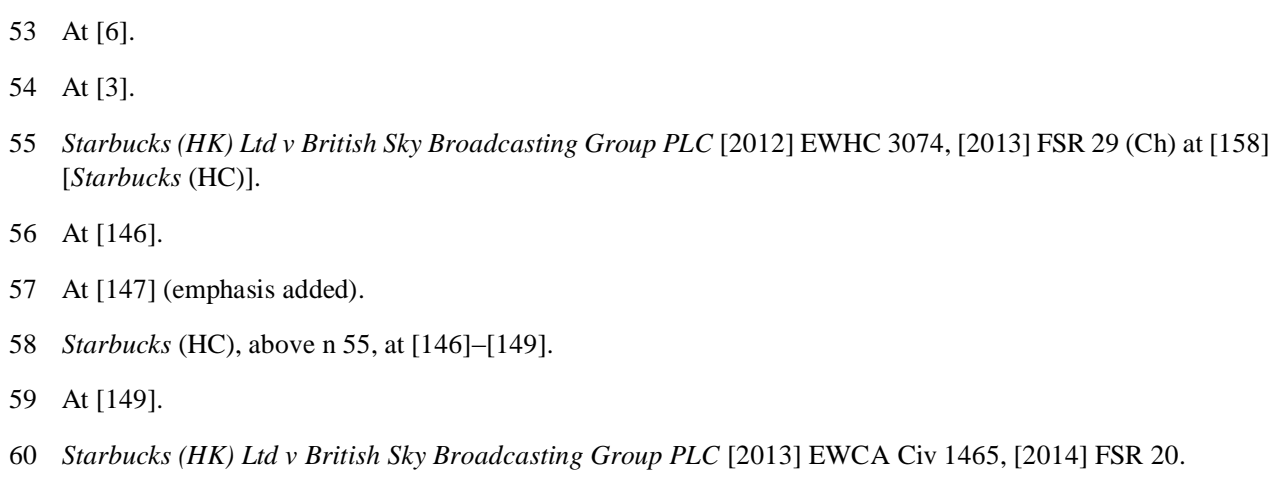


section of the public within the jurisdiction, or whether such a claimant must also establish a business with customers within the jurisdiction. ${ }^{61}$

\section{The Supreme Court Decision}

In framing the issue differently to Arnold $\mathbf{J}$ in the High Court, the Supreme Court had the latitude to depart from the traditional hard-line approach. Unfortunately, the Court did not seize this opportunity to do so. Lord Neuberger reaffirmed that for the goodwill limb to be satisfied in the United Kingdom, it is necessary for the claimant to show they have business and customers in the jurisdiction. ${ }^{62}$ The appeal was dismissed on the ground that the claimants had no customers in the jurisdiction and therefore no goodwill in the traditional sense. ${ }^{63}$ Thus, where a claimant's business is carried out abroad, it is not enough to show that a significant number of people in the jurisdiction know of their mark if those people are not customers in the United Kingdom, even if they are customers of the claimant when they go abroad. ${ }^{64}$ It could be enough for the claimant to show that they had some form of business presence in the jurisdiction, for example a booking agency in the United Kingdom acting on their behalf, which allows people to obtain the right to receive the claimant's service abroad. ${ }^{65}$ However, this did not avail the claimants in the present case.

It was further held that the people in the United Kingdom who get access to PCCM's NOW TV programmes via websites, or on various international airlines, were not customers of PCCM in the United Kingdom because there was no payment involved and the availability of the service in these outlets was intended to, and did, promote the Hong Kong business. ${ }^{66}$ This access to NOW TV in the United Kingdom was said to amount to no more than a reputation acquired through advertising which under the traditional approach is not enough to support a claim in passing off. ${ }^{67}$ In Lord Neuberger's view, upholding PCCM's case would be a "major and fundamental departure from the clear, wellestablished and realistic principles". 68

61 Starbucks, above n 1, at [1]

62 At [47].

63 At [47].

64 At [19].

65 At [52], in reliance on Athletes Foot Marketing Associates Inc v Cobra Sports Ltd [1980] RPC 343 (Ch).

66 At [67].

67 At [67].

68 At [66]. 


\section{E Critique of Lord Neuberger's Reasoning}

\section{Lord Neuberger's approach was orthodox, unconvincing and inappropriately simplistic}

Lord Neuberger superficially acknowledged the Supreme Court's ability to change the law. ${ }^{69}$ Unfortunately however, he took the safe option of retaining the status quo rather than disrupting the "the consistent view of the House of Lords and Privy Council from 1915 to $1990 " .{ }^{70}$ His basis for reaffirming the traditional approach was unconvincing as even he acknowledged that passing off was not the main focus of attention in any of the cases which considered this approach to be the law. ${ }^{71}$ These cases relied on Lord Macnaughten's statement in Muller that goodwill "has no independent existence". ${ }^{72}$ However, it is important to remember that Lord Macnaughten's statement in Muller was not directed at passing-off, nor was it intended to give an all-embracing definition of the concept of goodwill. ${ }^{73}$ Lord Neuberger and the traditional cases failed to acknowledge that Lord Macnaughten actually left open the possibility of goodwill transcending borders, saying that "where the reputation of a business is very widely spread ... it may be difficult to localise goodwill". ${ }^{74}$

The hard-line approach aids efficiency as it simplifies the test for goodwill, a core element for any passing off claim. It is understandable why judges gravitate towards grounding the definition of goodwill in customers in a jurisdiction, as this adds physicality to the intangible asset, making it separable and easier to identify. However, as will be discussed below, such simplicity is inappropriate today where the broader circumstances are highly relevant. A strict legal test which does not take the particular facts of a case fully into account is counterintuitive and risks undermining the very purpose of the tort. ${ }^{75}$

69 Starbucks, above n 1, at [49].

70 At [48], in reference to cases cited at [21]-[26]; Anheuser-Busch, above n 21; AG Spalding \& Bros, above $\mathrm{n}$ 20; Muller, above n 17, at 235; T Oertli AG v EJ Bowman (London) Ltd [1959] RPC 1; Star Industrial Co Ltd, above n 6, at 269; and the Advocaat case, above n 2, at 752.

71 Starbucks, above n 1, at [48].

72 Muller, above n 17, at 223.

73 Caterham Car Sales, above n 31, at [18]

74 Muller, above n 17, at 224

75 See Arpan Banerjee "Spill-Over Reputation in Passing Off Actions: Indian and English Law Compared" (2014) 14 OUCLJ 21 at 33. 


\section{More recognition ought to have been given to jurisdictions where the traditional approach has been departed from}

Lord Neuberger's view that there is no clear trend in the common law courts outside the United Kingdom away from the hard-line approach is mistaken. ${ }^{76}$ The main authority on which he based this view was the Singapore Court of Appeal decision in Staywell Hospitality Group Pty Ltd v Starwood Hotels \& Resorts Worldwide Inc, which largely followed the traditional United Kingdom approach. ${ }^{77}$ Arguably, Lord Neuberger placed too much weight on this decision, as the cases from other jurisdictions which he referred to indicate a considerable trend away from the hard-line approach in favour of the soft-line approach.

Lord Neuberger attempted to downplay the reasoning in the New Zealand Court of Appeal decision in Dominion Rent A Car, saying it did not take PCCM's case much further. ${ }^{78}$ He placed emphasis on Cooke $\mathrm{P}$ and Somers J's requirement that there must be a sufficient business connection with New Zealand before an Australian claimant could be entitled to protection. ${ }^{79}$ It seems that here, Lord Neuberger is assuming that by business connection, the judges meant that a plaintiff must have business activity or customers in New Zealand. However, this does not seem to be an accurate interpretation of their reasoning. Somers $\mathbf{J}$ expressly went on to say: ${ }^{80}$

In the case of a business having an international reputation which extends to New Zealand not much in the way of activity in New Zealand would ... be required to establish a goodwill. In such cases the reputation itself may be almost tantamount to goodwill, activity having importance in localising that reputation in New Zealand.

This suggests that Somers $\mathbf{J}$ considered reputation rather than business activity to be the most important component of goodwill. Similarly, Cooke P's statement that "goodwill transcends territorial boundaries" seems incompatible with a requirement that there must be goodwill in the form of separate customers in New Zealand as well as in Australia, especially in light of his comment that "the same persons may do both". ${ }^{81}$ From this it can be inferred that Cooke P might have found a sufficient business connection in the case where there are people in New Zealand who are customers of the

76 Starbucks, above n 1, at [51].

77 Staywell Hospitality Group Pty Ltd v Starwood Hotels \& Resorts Worldwide Inc [2013] SGCA 65, [2014] 1 SLR 911 at [135] (cited in Starbucks, above n 1, at [45]).

78 Starbucks, above n 1, at [41].

79 At [41].

80 Dominion Rent A Car, above n 12, at 420

81 At 406 and 411. 
claimant when they go to Australia, even if they are not paying customers when they are in New Zealand.

The Court in Dominion Rent A Car also held that an Australian company had a sufficient business connection with New Zealand based on its advertising in New Zealand and its general reputation in the Australian and New Zealand car rental markets. ${ }^{82}$ Therefore, contrary to Lord Neuberger's contention, it does seem like this decision assists PCCM's case that a significant reputation in the jurisdiction is sufficient to establish goodwill under the tort of passing off.

Lord Neuberger did acknowledge that the reasoning in the Australian case ConAgra does support PCCM's case. ${ }^{83} \mathrm{He}$ could not dispute nor conceal Lockhart J's outright rejection of the traditional approach as "no longer valid" nor Lockhart J's clear acceptance that reputation in the jurisdiction was sufficient. ${ }^{84}$ Lord Neuberger attempted to undermine the reasoning of this case by simply stating that the passing off claim failed in ConAgra, and that it had not been considered by the High Court of Australia. However, he fails to clarify that the claim failed under the soft-line approach because the plaintiff did not have a significant reputation in Australia, not because of any lack of customers or business activity. ${ }^{85}$ And, while the issue has not been considered by the High Court of Australia, this case has been accepted as leading authority and has been followed in a number of Australian cases and by the New Zealand High Court. ${ }^{86}$

The reasoning in ConAgra is strong and it emphasises that goodwill should not be looked at in the abstract, but rather in conjunction with the misrepresentation focus on whether the use of the mark by the defendant is likely to lead prospective purchasers to think it is connected to the plaintiff's product. ${ }^{87}$ Lord Neuberger does not adequately acknowledge the interaction of the three limbs of Lord Oliver's "classic trinity" in Starbucks. He says that in this case the second and third limbs are satisfied, yet at no later point in his judgment does he address these elements. ${ }^{88}$ In light of the discussion above, it is hard to understand how there can be misrepresentation and damage without goodwill, as the plaintiff would have no property which the defendant can be said to be likely to misrepresent or damage. ${ }^{89}$

82 At 406 .

83 Starbucks, above n 1, at [42].

84 At [42].

85 ConAgra, above n 27, at [116] and [133].

86 See Ami Australia Holdings Pty Ltd v Bade Medical Institute (Aust) Pty Ltd (No 2) [2009] FCA 1437; Winnebago Industries Inc v Knott Investments Pty Ltd (No 2) [2012] FCA 785; and Lacoste v Crocodile International PTE Ltd [2014] NZHC 2349 at [21].

87 ConAgra, above n 27, at [125].

88 Starbucks, above n 1, at [17].

89 See the discussion above in Part III(B)(1). 
It is also difficult to see why goodwill cannot be equated with reputation. In the Caterham Car Sales case, Harms JA postulates that the only component of the goodwill of a business that can be damaged by misrepresentation is its reputation, and this informs the likelihood of deception and damage. ${ }^{90}$ The smaller the reputation, the smaller the likelihood of deception and of damage, and vice versa. ${ }^{91}$ Unlike the cases that Lord Neuberger gave precedence to, this case encourages one to read Lord Macnaughten's dicta in Muller as a whole rather than relying on his specific dictum in isolation. ${ }^{92}$ Harms JA concludes that there is no need to distinguish between goodwill and reputation. ${ }^{93} \mathrm{He}$ supports this by drawing on Lockhart J's reasoning in ConAgra that goodwill was not meant to have a different meaning from reputation, and to hold that it does, only serves to complicate the matter. ${ }^{94}$

Therefore, these cases provide strong support for the proposition that the focus of the goodwill inquiry should be on whether there is a reputation sufficient to give rise to a real likelihood of misrepresentation and damage. They also advocate that physical locality should be an informing but not frustrating factor in this inquiry. Lord Neuberger's judgment would have been more cogent if he had properly addressed the strong arguments raised in these cases.

\section{The commercial reality should have been given more weight}

As noted by Lord Neuberger in Starbucks, the question of whether a foreign trader needs goodwill in the form of business and customers in the jurisdiction "is of particularly acute significance in the age of global electronic communication". ${ }^{95} \mathrm{He}$ did not, however, fully come to terms with the undeniable reality that the traditional approach is rooted in the past and that its rigidity is inappropriate and incompatible in our modern world, which is becoming ever smaller and in which abstract intangible assets are proliferating.

The fast and dominant development of communication systems, particularly the internet, has lead to information being transmitted as soon as it is published so that it is accessible almost anywhere in the world. This means that the reach of the attractive force of a trader's reputation can conceivably stretch to other parts of the world, even countries where their goods or services are not available. ${ }^{96}$ The insistence on a local customer base in the jurisdiction is therefore impractical and conflicts with

90 Caterham Car Sales, above n 31, at [16].

91 At [20].

92 Caterham Car Sales, above n 31, at [16].

93 At [16]-[19]

94 At [21].

95 Starbucks, above n 1, at [1].

96 See generally Whirlpool, above n 30, at [12] and [29]; EasyJet v EasyJet (2013) 55 PTC 485 (Delhi High Court); and Cadbury v Lotte (2014) 57 PTC 422 (Delhi High Court). 
the needs of contemporary business and international commerce. ${ }^{97}$ This is supported by Frankel who observes that "in today's world of instantaneous communication, easy transport and international travel, the application of such a restrictive approach to reputation could not survive and, indeed, has not survived". ${ }^{98}$

It is conceivable that a claimant's international business may have a significant reputation for their mark among a sufficient number of prospective purchasers in a jurisdiction, for example through publicity on television, the internet and/or travel. In such a case, it may also be likely that the use of that mark by a domestic business will be likely to lead people to think it emanates from or is connected to the claimant's business. It seems nonsensical to hold, as a matter of law, that such a claimant does not have goodwill in that jurisdiction simply because they do not have paying customers. Therefore, the fact that there would be a real likelihood of misrepresentation and damage means that a finding of no goodwill would frustrate the fundamental rule of the tort that "no man may pass off his goods as those of another". ${ }^{99}$ In the words of Browne-Wilkinson VC: $: 100$

... the law will fail if it does not try to meet the challenge thrown up by trading patterns which cross national and jurisdictional boundaries due to a change in technical achievement.

Lord Neuberger did not adequately recognise the force of these arguments. If he had, it is difficult to comprehend how he could have adopted the hard-line approach, which treats goodwill as if it exists as an "archipelago", when the modern reality is that it exists in "a manner more akin to a tractor beam". ${ }^{101}$

\section{The soft-line approach is consistent with the notion of territoriality}

Lord Neuberger thought the traditional approach was supported by the notion of territoriality, which is central to both trademark law and passing off. ${ }^{102}$ However, while trademarks are strictly territorial in scope and, as a matter of law, do not extend beyond nationwide protection, ${ }^{103}$ goodwill, as a matter of fact, may transcend territorial boundaries. ${ }^{104}$ The soft-line approach is still sufficiently

97 ConAgra, above n 27, at 504.

98 Frankel, above $\mathrm{n}$ 4, at 608.

99 The Jif Lemon case, above n 3, at 499.

100 Pete Waterman Ltd v CBS United Kingdom Ltd [1993] EMLR 27 (Ch) at [51].

101 Lauriat, above n 41, at 79.

102 Starbucks, above n 1, at [55].

103 Trademark protection is based on registration in the relevant jurisdiction. See Frankel, above n 4, at 484; and Graeme Dinwoodie "Trademarks and Territory: Detaching Trademark Law from the Nation-State" (2004) 41 Hous L Rev 885 at 892-893.

104 Dominion Rent A Car Ltd, above n 12, at 406. 
territorial in that it requires goodwill in the form of a significant reputation to be established in the relevant jurisdiction. ${ }^{105}$ However, it also recognises the reality that this reputation may come from sources in other jurisdictions and therefore, it is more practical. ${ }^{106}$

\section{Protection under passing off is justified even in light of protection under trademark law}

As noted by Lord Neuberger, s 56 of the Trade Marks Act 1994 (UK) (which gives effect to art 6bis of the Paris Convention $)^{107}$ reduces the likelihood of harsh outcomes for international businesses with trademarks that are unregistered in the United Kingdom. ${ }^{108}$ This provision enables businesses in a Convention country to restrain, by injunction, the use of their mark if it is shown that it is "wellknown in the United Kingdom" and the use is likely to cause confusion. ${ }^{109}$

Lord Neuberger saw considerable force in the argument that if PCCM's case is correct, it would effectively render the purpose of s 56 redundant. ${ }^{110}$ However, while s 56 negates the disadvantages of the hard-line approach, it is still narrower in scope than an action in passing off. ${ }^{111}$ As shown by Starbucks, s 56 does not apply when an international business has a trademark which is not entitled to protection under the Paris Convention. ${ }^{112}$ There is also great uncertainty surrounding the meaning of "well-known" marks, and the doctrine varies considerably within and between jurisdictions. ${ }^{113}$

The threshold for well-known marks appears to be high, ${ }^{114}$ and it has been criticised as restricting protection to marks which are "world famous", creating unpredictability and unfairness. ${ }^{115}$ This high threshold suggests that small businesses and niche brands may be disadvantaged. Fame is often analogous to size, meaning bigger businesses are considered more famous and are given more

105 Caterham Car Sales, above n 31, at [20]; and ConArga, above n 27, at [132].

106 Caterham Car Sales, above n 31, at [20]; and Dominion Rent A Car, above n 12, at 406.

107 Paris Convention for the Protection of Industrial Property (opened for signature 20 March 1883, entered into force 7 July 1884, and amended 2 June 1934, and 14 July 1967), art 6bis [Paris Convention].

108 Starbucks, above n 1, at [64].

109 Trade Marks Act 1994 (UK), s 56(1).

110 Starbucks, above n 1, at [65].

111 See Banerjee, above $\mathrm{n} 75$, at 17

112 Trade Marks Act 1994 (UK), s 56(1); and Starbucks (HC), above n 55, at [4]-[9].

113 See generally Frederick Mostert Famous and Well-known Marks: An International Analysis (International Trade Mark Association, New York, 2004); and J Thomas McCarthy McCarthy on Trademarks and Unfair Competition (4th ed, Thomson Reuters, Eagan, 2011).

114 Case C-375/97 General Motors Corp v Yplon [1999] ECR I-5444 at [19].

115 See Jitka Smith "Budweiser or Budweiser?" (1999) 32 J Marshall L Rev 1251 at 1284. 
rights. ${ }^{116}$ Small businesses may only have "niche market fame", which is where the mark enjoys a high level of recognition that is confined to a certain segment of the public, a smaller geographic area, a particular industry or a limited group of specialised purchasers or users. ${ }^{117}$ Therefore, these businesses will not be able to show that their mark is world famous, meaning they will be less likely to qualify for protection under s 56.

The soft-line approach, which would extend protection to all cases where an international business can show that it has a significant reputation for its mark among a sufficient number of prospective purchasers, is more capable of offering protection to small or niche businesses. Prospective purchasers may include a certain segment of the public or industry in the jurisdiction. If a mark has a significant reputation among that portion of the jurisdiction, there would be a real likelihood of deception if a domestic business were to use the international business's mark to attract those people. In such a case, passing off under the soft-line approach would protect that business's mark notwithstanding that it is not world famous. ${ }^{118}$ Therefore, the current statutory trademark protection is conceivably inadequate and discriminatory, indicating that the expansion of the tort of passing off could still serve an important purpose in remedying this situation.

From another point of view, it is noteworthy that Parliament has developed trademark law so that it offers protection to international businesses based on their reputation in the United Kingdom, irrespective of any evidence of business or customers. This suggests that the development of the common law in that part of the same field ought to proceed upon a parallel rather than a diverging course. ${ }^{119}$

\section{Lord Neuberger did not strike the appropriate balance between protection and competition}

Lord Neuberger's decision ultimately rested on his assessment of the appropriate balance between the public interests in not unduly hindering competition and encouraging development, on the one hand, and in encouraging, by rewarding through protection, originality, effort and expenditure, on the

116 At 1284.

117 See J Thomas McCarthy "Proving a Trademark Has Been Diluted: Theories or Facts?" (2003) 41 Hous L Rev 713 at 731-733 (2004); and McCarthy, above n 113, at 1173-1174.

118 See Caterham Car Sales, above n 31, at [20]; and ConArga, above n 27, at [132].

119 The Advocaat case, above n 2, at 743. 
other. ${ }^{120}$ His view was that if mere reputation was enough to establish a passing off action, this "would tip the balance too much in favour of protection". ${ }^{121}$ He warned that if PCCM's case were correct: ${ }^{122}$

... it would mean that a claimant could shut off the use of a mark in this jurisdiction even though it had

no customers or business here, and had not spent any time or money in developing a market here - and

did not even intend to do so.

First, it can be noted that Lord Neuberger's caution against businesses unjustifiably being given "monopoly powers" is misconceived. ${ }^{123}$ Passing off only provides limited protection of the specific name, mark or get up and does not prevent competitors from entering the market with a different name, mark or get-up. Therefore, it is not a significant barrier to other businesses entering the market and does not provide the plaintiff with monopoly powers in any true or practical sense.

Moreover, his claim that the traditional approach is in the interest of consumers is questionable as it is not in consumers' interest to be misled into thinking that a product or service is that of an established and trusted brand when in fact it is not. Consumers ought to be able to rely on businesses' reputations as an indicator of quality, and an approach which does not adequately protect consumers from misrepresentation cannot be said to be in their interests. Similarly, businesses ought to be protected from others passing off goods as theirs and leveraging their established reputations. If the law does not reward businesses' effort and expenditure in distinguishing their products, they may be disincentivised from doing so. ${ }^{124}$ Denying businesses such justifiable protection runs the risk of causing passing off to become a tool that prevents the very competition it is designed to protect. ${ }^{125}$

There is merit in Lord Neuberger's concern that, given that it is so easy to penetrate into people's minds almost anywhere in the world as a result of technical advances and travel, businesses could be able to claim some reputation within virtually every jurisdiction. ${ }^{126}$ It is true to some extent that if goodwill is treated interchangeably with reputation and the requirement of customers within a jurisdiction is dropped, there is likely to be increased and more widespread protection. ${ }^{127}$ Prima facie, the soft-line approach may seem to give big international businesses too much protection. This is concerning as it is undesirable to hinder the development of small local businesses, who adopt names

120 Starbucks, above n 1, at [61].

121 At [62].

122 At [63].

123 Starbucks, above n 1, at [62].

124 See Apple Computer Inc v Apple Leasing \& Industries (1961) SCR (2) 805 (Supreme Court of India) at [159].

125 Levi Strauss \& Co v Kimbyr Investments Ltd [1994] 1 NZLR 332 (HC) at 362 per Williams J.

126 Starbucks, above n 1, at [63].

127 At [63], referring to his discussion at [60]-[62]. 
in their domestic territories with bona fide intentions, in cases where international businesses have not made an effort to develop a market there.

However, Lord Neuberger's concerns fail to take into account that it remains a requirement under the soft-line approach that the defendant's use of the plaintiff's name, mark or get-up must give rise to a real risk of misrepresentation with consequential injury to the plaintiff. ${ }^{128}$ Therefore, if an international business has not developed a market for their mark in the jurisdiction, and has no intention of doing so, it is unlikely that they will have a significant reputation among a sufficient section of prospective purchasers in that jurisdiction. Nor are they likely to be able to show that people will be misled into thinking a local business's use of that mark is connected to their business, as people would be unlikely to expect them to operate in the jurisdiction. It will only be in cases where a local business "set[s] up business for the first time with a mark deceptively similar to one already in use and having a truly distinctive reputation in the same market" that protection will be provided under the soft-line approach. ${ }^{129}$

A further way to guard against excessive protection is to require a considerably high threshold for the reputation, misrepresentation and damage limbs, in order to fetter the protection provided under the tort and ensure that it operates within appropriate boundaries. ${ }^{130}$ This seems to be how the courts in the jurisdictions that follow the soft-line approach apply the test, as evidenced by the result in ConAgra. ${ }^{131}$ Therefore, Lord Neuberger's concerns in relation to unduly hindering competition and development are overstated. The appropriate balance can conceivably be achieved by the soft-line approach. This does not give protection to all businesses with international reputations but only those that are able to satisfy the high threshold required under all three limbs. If this high threshold is met, protection would be justified and would fulfil the purpose of the tort to prevent a trader passing off his goods as anothers.

\section{Legal uncertainty and consequential changes are not good justifications for retaining archaic and unpractical law}

Lord Neuberger was also concerned that changing the common law may generate legal uncertainty and could lead to other consequential changes. ${ }^{132}$ It is acknowledged that excessive judicial innovation is to be warned against. ${ }^{133}$ However, adopting the soft-line approach ought to be viewed

128 See the second and third limbs of the three-fold test for the soft-line approach above in Part III(B).

129 Dominion Rent A Car, above n 12, at 406 per Cooke P.

130 Lauriat, above n 41, at 89.

131 ConAgra, above n 27, at [94] and [145]: the plaintiff was held to have an insufficient reputation in Australia to support a finding of goodwill under the soft-line approach.

132 Starbucks, above n 1, at [49].

133 Lord Bingham "The Rule of Law" (2007) 66 CLJ 67 at 71. 
as permissible judicial innovation as it would involve altering the law's direction by a "few degrees" in response to changes in the commercial landscape, as opposed to setting it in a new direction. ${ }^{134}$ Generally, the results of this approach are also likely to be foreseeable and predictable. This is because if it is clear that a claimant's reputation is such that a defendant's use of their name, mark or get-up would conceivably lead to misrepresentation and likely damage to the claimant then there will foreseeably be a finding of goodwill and the passing off claim will succeed, and vice versa.

While the results in borderline cases may be less predictable, this risk is not grave enough to justify retaining the status quo when it is out of touch with commercial reality. The state of the law is already uncertain, and this can be viewed as the inevitable consequence of fast-paced changing technology, particularly the growth of the internet. ${ }^{135}$ There does, however, appear to be a relatively strong trend away from the hard-line approach in common law courts outside the United Kingdom. If the Supreme Court had followed this trend, then arguably they would have done more to aid certainty than hinder it.

\section{Lord Neuberger should have placed more importance on the facts of the case}

The test for goodwill should be a factual and evidential inquiry as opposed to a strict legal test. Each of the three Law Lords emphasised that the courts must focus on the particular facts of the case before them, rather than on a simple reapplication of the same test, even if two cases look relatively similar. ${ }^{136}$

Lord Neuberger acknowledged cases that support the notion that the geographical boundaries of any goodwill should be a question of fact in each case, rather than one of law. ${ }^{137}$ However, he favoured the application of a strict legal test which requires customers in the jurisdiction, irrespective of any reputation a mark may have in the jurisdiction, however great that may be. ${ }^{138}$ This led him into the trap of ignoring evidence of misrepresentation and damage despite saying that these limbs were satisfied. ${ }^{139}$ In light of earlier discussion, this is arguably the strongest evidence that goodwill exists

134 At 71, Lord Bingham says that this is permissible.

135 See generally Michael A Geist "Is There a There There? Toward Greater Certainty for Internet Jurisdiction" (2001) 16 Berkeley Tech LJ 1345 at 1347; and David Johnson and David Post "Law and Borders: The Rise of Law in Cyberspace" (1996) 48 Stan L Rev 1367.

136 Frankel, above n 4, at 567, in reference to Lord Diplock, Lord Fraser and Lord Oliver.

137 Starbucks, above n 1, at [31], in reference to Baskin-Robbins Ice Cream Co v Gutman [1976] FSR 545 (Ch) at 547-548; and Maxim's Ltd v Dye [1977] 1 WLR 1155 (Ch) at 1159 and 1162.

138 At [32] and [47].

139 At [17]. 
and yet Lord Neuberger's hard-line approach does not even consider it until the customer requirement is satisfied. ${ }^{140}$

It is impractical to focus solely on a rigid requirement of customers in the jurisdiction when such an approach may lead to a finding under the goodwill limb which is at odds with the other limbs of the test. If goodwill cannot be established as a matter of law in cases where there is clear evidence of misrepresentation, this risks undermining the purpose of the tort. A substantive factual inquiry under the soft-line approach would not allow such injustices to occur as it would take all these factors into account when determining whether there is goodwill deserving of protection.

\section{F Starbucks under the Soft-Line Approach}

The key issue under this approach is whether, at the relevant date, PCCM had a significant reputation for their name "NOW TV", which meant that a sufficient number of prospective purchasers in the United Kingdom would likely believe that Sky's NOW TV emanated from the same or a connected source.

Arnold $\mathbf{J}$ found that PCCM had a substantial reputation for NOW TV in the United Kingdom among Chinese-speaking residents who were previously familiar with PCCM's service. ${ }^{141} \mathrm{He}$ also held that there was a likelihood that those residents would wrongly believe that Sky's NOW TV emanates from the same or a connected source as the names and services are essentially identical. ${ }^{142}$ These findings may lead to a prima facie view that PCCM would be found to have goodwill in the United Kingdom under the soft-line approach.

Alternatively, the soft-line approach may still lead to the same result. Arnold J's finding that PCCM had a substantial reputation for NOW TV in the United Kingdom was limited to the Chinesespeaking community in the United Kingdom. PCCM's claim in the High Court and Supreme Court was that they had a reputation among a significant number of people in the United Kingdom, as opposed to Chinese-speaking residents in the United Kingdom. ${ }^{143}$ In relation to the prospective purchasing public, which includes all United Kingdom citizens that might be exposed to Sky's NOW TV service, PCCM were found to have a reputation that was modest, but more than de minimis. ${ }^{144}$ Therefore, it is quite possible that PCCM would fail to reach the high threshold required under the soft-line approach of showing they have a significant reputation in the relevant forum in which they made their claim.

140 See the discussion in Part III(B)(2) and Part IV(E)(2).

141 Starbucks (HC), above n 55, at [158].

142 At [158].

143 Starbucks (HC), above n 55, at [144]; and Starbucks, above n 1, at [18].

144 Starbucks (HC), above n 55, at [146]. 
The likelihood of a failure to find goodwill is all the more likely in light of the weak distinctiveness of the name "NOW TV" due to its use of the descriptive word "NOW". ${ }^{145}$ As previously noted, the weaker the plaintiff's reputation in a particular mark or get-up, the weaker the argument for misrepresentation by the defendant. ${ }^{146}$ Therefore, there is a real possibility that PCCM's modest reputation for NOW TV and the relatively small likelihood of confusion among the general prospective purchasing public in the United Kingdom would have been insufficient to support a finding of goodwill, even under the soft-line approach. ${ }^{147}$

Starbucks is a borderline case making it hard to say decisively whether goodwill would be established under the soft-line approach. By contrast, the facts of a case like the Crazy Horse case, where the plaintiff had a significant international reputation and there was strong evidence of deliberate misrepresentation, would be very likely to support a finding of goodwill under the soft-line approach. ${ }^{148}$ This shows that every case must be decided based on its own particular facts, requiring an in-depth analysis to be undertaken by judges. Although this may be more onerous on judges and may in some cases reach the same results as the hard-line approach, such results are arguably more justified as they are tied to the facts of the case, as opposed to any legal fallacy that goodwill never transcends boundaries, when it is widely acknowledged that it may in fact do so.

\section{OUTLOOK}

\section{A Is New Zealand Likely to Follow the House of Lords Decision in Starbucks?}

Given the clear trend of the New Zealand decisions in favour of the soft-line approach it is unlikely that New Zealand courts will follow the United Kingdom Supreme Court's traditional approach. ${ }^{149}$ It has long been recognised that for a business which has an international reputation that extends to New Zealand, not much in the way of business activity in New Zealand is required to establish goodwill. ${ }^{150}$

145 At [108]-[115], and Arnold J's reference at [142] to Lord Simonds' statement in Office Cleaning Services Ltd $v$ Westminster Window and General Cleaners Ltd (1946) 63 RPC 39 (HL) at 43 that "so long as descriptive words are used by two traders ... it is possible that some members of the public will be confused".

146 See Caterham Car Sales, above n 31, at [20]; and Frankel, above n 4, at 591

147 This is supported by Arnold J's dicta in Starbucks (HC), above n 55, at [141]-[157].

148 Crazy Horse, above n 21, at 588: the defendant company was found to have chosen the identical name with the sole purpose of "cashing in" on the reputation of the plaintiff.

149 See generally Dominion Rent A Car, above n 12; Crusader Oil NL v Crusader Minerals Ltd, above n 26; Midas International Corporation v Midas Autocare Ltd (1987) 2 TCLR 491 (HC); Pioneer Hi-Bred Corn Co v Hy-Line Chicks Pty Ltd [1978] 2 NZLR 50 (CA); Esanda Ltd v Esanda Finance Ltd, above n 26; VB Distributors Ltd v Misubita Electrical Industrial Co Ltd [1999] 53 IPR 466 (HC) at [83]; Ivy Group Presidents (t/a The Ivy League) v Pacific Dunlop (Asia) Ltd (2000) 66 IPR 202 (HC); Valley Girl Co Ltd v Hanama Collection Pty Ltd (2005) 66 IPR 214 (HC); and Muzz Buzz, above n 26.

150 Dominion Rent A Car, above n 12, at 420; confirmed in Muzz Buzz, above n 26, at [75]. 
Under this approach, an international business may have goodwill which will extend to New Zealand if there is a sufficient business connection with New Zealand, for example through advertising accompanied by a general industry reputation in the New Zealand market, ${ }^{151}$ and exposure through travel. ${ }^{152}$ It is therefore evident that the New Zealand approach is grounded in the facts of the case as opposed to a general legal principle that requires customers and businesses in the jurisdiction. ${ }^{153}$

The diminishing importance of business activity in the jurisdiction is consistent with the decline of international boundaries, which is particularly apparent in trans-Tasman situations. ${ }^{154}$ According to Gill the "single biggest factor in the development of the common law of extraterritorial goodwill has been a nation's approach to international trade". ${ }^{155}$ The very substantial increase in two-way trade between New Zealand and Australia from 1966 points in favour of the soft-line approach which accepts that "slop-over" reputation between the two countries ought to be sufficient for a finding of goodwill in either of those jurisdictions. ${ }^{156}$

The soft-line approach also aligns more closely with New Zealand's legislative trend, in particular the New Zealand Fair Trading Act 1986, which has similar elements to passing off. In this Act, there is no requirement of goodwill; the focus is on whether there has been misleading or deceptive conduct. ${ }^{157}$ This looser approach is largely due to a lack of any need to show loss or injury to any property right under the Act, as is required under the tort of passing off (and hence the need to establish goodwill). However, the legislation reflects that Parliament has, to a certain extent, favoured the public interest demands of protecting consumers from deception over the general public interest in competition. Consistent with Lord Diplock's statement in the Advocaat case, the New Zealand courts appear to have proceeded on a "parallel rather than a diverging course" to this approach of Parliament when developing the common law in this part of the same field. ${ }^{158}$ It is thus unlikely that they would change course and follow the United Kingdom Supreme Court's decision in Starbucks.

151 Dominion Rent A Car, above n 12, at 420.

152 Esanda Ltd v Esanda Finance Ltd, above n 26.

153 Dominion Rent A Car, above n 12, at 420 per Somers J.

154 Midas International Corporation v Midas Autocare Ltd, above n 149, at 357.

155 A Kelly Gill "Protecting Extraterritorial Goodwill: Exploring the Impetus Behind a Common Law" in Catherine W Ng, Lionel Bently and Giuseppina D'Agostino (eds) The Common Law of Intellectual Property: Essays in Honour of Professor David Vaver (Hart Publishing, Oxford, 2010) at 353.

156 Dominion Rent A Car, above n 12, at 407 per Cooke P, in reference to the New Zealand-Australia Free Trade Agreement, accelerated by the CER Heads of Agreement 1982 and the Australia-New Zealand Closer Economic Relations Trade Agreement 1983. See the New Zealand Official Year Book 1986-87 at 647 as cited in Muzz Buzz, above n 26, at [74].

157 Fair Trading Act 1986, s 9.

158 The Advocaat case, above n 2, at 743. 


\section{B Is it likely that the United Kingdom will Depart from the Traditional Approach in Future?}

United Kingdom judges have consistently favoured the more certain and orthodox approach over the less predictable and contemporary soft-line approach, reflecting their discomfort with the new and unknown. ${ }^{159}$ Previously, there may have been an argument that the United Kingdom might adopt New Zealand and Australia's "slop-over" goodwill approach, at least with their European neighbours, with whom to date, they have always had close trade ties. This prospect seems less likely however in wake of Brexit, with the United Kingdom choosing to leave the European Economic Community. Though it is unknown exactly how Brexit will affect the United Kingdom's approach to international trade, it does appear that it is distancing itself and putting up barriers to the other parts of the world rather than reducing them. ${ }^{160}$

Therefore, it seems unlikely that the United Kingdom will depart from the traditional approach any time soon. This leaves the overall common law for the tort of passing off inconsistent and conflicting, which can only result in inevitable uncertainty despite claims that the United Kingdom Supreme Court has clarified the law. This is unfortunate and may risk the tort becoming less effective as a means of preventing the passing off of goods in the modern commercial landscape.

\section{CONCLUSION}

The Supreme Court ought to have departed from the old and impractical traditional approach. It should have adopted the soft-line approach, which is more in line with modern commercial reality. The decision in Starbucks was unremarkable as it left the law in the United Kingdom static and at odds with other common law jurisdictions. The United Kingdom's hard-line approach does not appear to strike the appropriate balance between protection and competition, but rather gives rise to the risk of anti-competitive results as a consequence of inadequate protection for international businesses. This view is reinforced by the limited and uncertain statutory protection which supports the need for the expansion of passing off. The soft-line approach, on the other hand, offers more adequate protection and has the ability to remain sufficiently pro-competitive if the other limbs of misrepresentation and damage are applied so that they inform and fetter the goodwill inquiry.

Overall, the United Kingdom's approach to goodwill is orthodox and inappropriately simplistic when it should be contemporary and grounded in the particular facts of the case. The strict legal test for goodwill applied by the courts in England and Wales is at odds with the flexible nature of passing off, and it risks undermining the fundamental rule of the tort that one should not be allowed to pass

159 See Anheuser-Busch, above n 21; AG Spalding \& Bros, above n 20; Muller, above n 17, at 235; T Oertli AG $v$ EJ Bowman (London) Ltd [1959] RPC 1 (HL); Star Industrial Co Ltd, above n 6, at 269; and the Advocaat case, above n 2 , at 752 .

160 Thomson Reuters "EU referendum: Vote to Leave puts Britain on uncertain course" (24 June 2016) CBC News <www.cbc.ca>. 
off the goods of another. The soft-line approach re-positions this rule to the core of the goodwill inquiry, and it is in this way that it is likely to lead to more justifiable results. 
(2017) 48 VUWLR 